\title{
Working capital Management, Investment and Financing constraints in Companies listed on the Tehran, Iran Stock Exchange
}

\author{
Fatemeh Baghiyan ${ }^{1,2}$ \\ ${ }^{1}$ Nuclear Science and Technology Research Institute, Plasma Physics and Nuclear Fusion Research School, Tehran, Iran \\ ${ }^{2}$ Department of accountancy, Azad University of Gazvin, Gazvin baragin, Iran
}

\section{Email address:}

parbag@yahoo.com

\section{To cite this article:}

Fatemeh Baghiyan. Working Capital Management, Investment and Financing Constraints in Companies Listed on the Tehran, Iran Stock Exchange. International Journal of Business and Economics Research. Vol. 2, No. 6, 2013, pp. 130-133. doi: 10.11648/j.ijber.20130206.12

\begin{abstract}
Since the level of fixed investment is costly for industries, they always search for ways to maintain it; however, financing constraints prevent the realization of this goal. A panel of over 134 stock firms over the period 2005-2011 was used to study the linkages between financing constraints and investment in fixed and working capital. To this end we have analyzed the relation between tangible fixed assets, investment, cash flow, tangible fixed assets, working capital and fixed investment. In this studies we changes variables and hypotheses. The results obtained indicate that an active management of working capital may help firms alleviate the effects of financing constraints on fixed investment [9].
\end{abstract}

Keywords: Working Capital Management, Investment, Cash Flow, Tangible Fixed Assets, Fixed Investment [9]

\section{Introduction}

The current study was conducted on a panel of 134 stock firms over the period 2005-2011. We initially ran fixed investment and working capital investment regressions as a function of cash flow. Then we focused on investment in fixed capital, as a significant determinant of growth, both generally (Bernanke and Gurkanyan [6]; Bond and Schiantarelli, [7] and in China (Knight and Ding, [8].

In the last three decades, the Chinese economy has been characterized by persistently high fixed investment rates and phenomenal growth rates [1]. Considering that the Chinese financial system is poorly developed, this can been seen as a puzzle [2]. Several authors have tried to find explanations for it. Among these, Ayyagari [3] focused on the role of informal finance, and concluded that it is not because of their access to informal financial sources that Chinese firms were able to grow, despite limited access to external financing. Cull [4] concluded that access to trade credit did not play a significant role in explaining this puzzle. Guariglia [5] demonstrated that the Chinese miracle growth was driven by highly productive private firms, which were able to accumulate very high cash flows.

Active components of working capital can decrease financing constraints on fixed investment firms. Research findings show that firms with high working capital display high sensitivities to investment in working capital to cash flow (WKS) and low sensitivities to investment in fixed capital to cash flow (FKS). We found that, despite severe external financing constraints, those firms with high WKS and low FKS exhibit the highest fixed investment rates.

All companies, hoping to improve company performance focus on seven main accounting practices. The level of fixed investment is costly for firms, so they search for ways to save it. Financing constraints, however, prevent the realization of this goal. Because companies cannot without cost, Eliminate fluctuations in cash flow from foreign funds. Limited companies can change their working capital, Effects of sudden changes in cash flows on fixed investment eliminate with putting investment in working capital in the negative level. That In this case, the working capital adjustment costs, followed by the amount of smoothing depends on the initial capital investment is involved, the variable that helps to strengthen the company's balance sheet. But if companies are faced with financial constraints, investment in fixed capital investment of available funds will be in opposition. In this case, the fixed capital investment as endogenous variables in is egression of fixed capital coefficient will be negative.

The second empirical prediction is that have not 
diminished recent studies attention to the profound impact of financial constraints on investment. The coefficient of cash flow in fixed investment regressions that in many recent studies come. Only short-term impact of the shock of cash flow after change optimizes investments will do. The fixed capital investment as a (an important determinant of growth), and in particular the role of working capital management as well as the explanation of why, despite some significant limitations, they have been able to finance their investment in a many high rate, be examined.

Appropriate management working capitals can financial constraints investment in fixed assets decrease.

\section{Research Methods and Processes}

An acting management of working capital may help firms to alleviate the effects of financing constraints on fixed investment.

\section{The Following Equations Are Studied}

$$
\left(\frac{\mathrm{I}_{\mathrm{it}}}{\mathrm{K}_{\mathrm{it}}}\right)=\beta_{0}+\beta_{11}\left(\frac{\mathrm{CF}}{\mathrm{K}_{\mathrm{it}}}\right)+\beta_{2} \text { Lev }+\beta_{3} \text { Growth }+\beta_{4} \text { size }+\varepsilon_{\mathrm{it}}
$$

$$
\begin{gathered}
\left(\frac{I W K_{i t}}{K_{i t}}\right)=\beta_{0}+\beta_{11}\left(\frac{C F_{i t}}{K_{i t}}\right)+\beta_{2} L e v+\beta_{3} \text { Growth }+\beta_{4} \text { Size }+\varepsilon_{i t} \\
\left(\frac{I_{i t}}{K_{i t}}\right)=\beta_{0}+\beta_{11}\left(\frac{C F_{i t}}{K_{i t}}\right)+\beta_{12}\left(\frac{C F_{i t}}{K_{i t}}\right)^{*} L O W W K_{i t}{ }^{\prime} H I G H W K_{i t}+\beta_{2} L e v+ \\
\beta_{3} \text { Growth }+\beta_{4} \text { Size }+\varepsilon_{i t} \\
\left(\frac{I W K_{i t}}{K_{i t}}\right)=\beta_{0}+\beta_{11}\left(\frac{C F_{i t}}{K_{i t}}\right)+\beta_{12}\left(\frac{C F_{i t}}{K_{i t}}\right)^{*} L O W W K_{i t}{ }^{\prime} H I G H W K_{i t}+\beta_{2} L e v+ \\
\beta_{3} \text { Growth }+\beta_{4} \text { Size }+\varepsilon_{i t}
\end{gathered}
$$

\section{Data Description}

The following table index dispersion parameters such as mean and median, standard deviation and skewness for different variables were calculated. There are large are as in the middle of a big core data shows, because them and is influenced by the amount of skew in the data distribution to the right. For example, variables such as CF / K * Low wk, High wk and DEBT distribution is skew to the right.

The mean and median values of the variables are closely.

\begin{tabular}{|c|c|c|c|c|c|c|c|c|c|}
\hline maximum & minimum & strain & skewers & $\begin{array}{l}\text { Standard, } \\
\text { deviation }\end{array}$ & median & Mean & $\begin{array}{l}\text { Observation } \\
\text { Perth } \\
\end{array}$ & observations & variables \\
\hline $1 / 00$ & $-2 / 02$ & $0 / 32$ & $-0 / 96$ & $0 / 33$ & $0 / 07$ & $0 / 09$ & 2 & 802 & $\mathrm{I} / \mathrm{k}$ \\
\hline $5 / 98$ & $-3 / 78$ & $0 / 36$ & $0 / 31$ & $1 / 03$ & $0 / 26$ & $0 / 42$ & 3 & 801 & $\mathrm{IWK} / \mathrm{k}$ \\
\hline $4 / 26$ & $-2 / 33$ & $9 / 29$ & $1 / 65$ & $0 / 65$ & $0 / 02$ & $0 / 07$ & 0 & 804 & $\mathrm{CF} / \mathrm{k}$ \\
\hline $2 / 38$ & $-1 / 66$ & $29 / 05$ & $2 / 00$ & $0 / 25$ & $0 / 00$ & $0 / 00$ & 0 & 804 & $\mathrm{CF} / \mathrm{K}^{*}$ Low wk,Highwk \\
\hline $8 / 52$ & $4 / 25$ & $0 / 92$ & $0 / 71$ & $0 / 65$ & $5 / 54$ & $5 / 56$ & 0 & 804 & $\log$ Size \\
\hline $0 / 95$ & $0 / 00$ & $14 / 22$ & $3 / 30$ & $0 / 12$ & $0 / 06$ & $0 / 10$ & 0 & 804 & DEBT \\
\hline $2 / 97$ & $-1 / 00$ & $8 / 75$ & $1 / 51$ & $0 / 36$ & $0 / 14$ & $0 / 16$ & 0 & 804 & Growth \\
\hline
\end{tabular}
These characteristics are very important. Variables are symmetrically distributed. Symmetry is a property of the normal distribution. (Stretching and skewness of the normal distribution is zero).

Table1: Show the Descriptive Statistics for Variables

$\mathrm{I} / \mathrm{K}$ and the $\mathrm{IWK} / \mathrm{K}$ respectively $0 / 96$ and $0 / 31$, Skewness of the dependent variables, which is similar to the distribution of this variable is normally distributed, the variables are distributed approximately symmetrical.

\subsection{Analysis Panel}

Data integration panel (Panel) without fixed effects, fixed effects and random effects for data analysis, was used. Fixed or random effects model to determine the suitability of Lymr test (Chow) test was used Hausman.

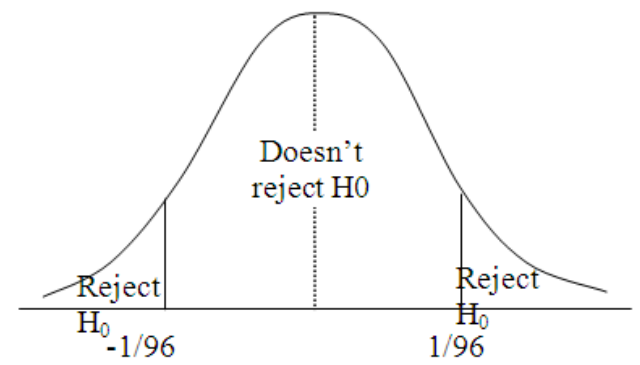

$$
t_{\beta_{i}}=\frac{\beta_{i}-0}{S_{\beta_{i}}} i=0,1,2,3,4
$$

\subsection{The Process of Choosing the Right Model}

1. There is no effect of the model is tested (test Lymr).

2. Second, the model with random effects vs. fixed effects model is test (Hausmantest).

3. Among the three models: without effects model, with fixed effects and random effects model and the best model is selected.

4. The mater of each independent variable and control will be discussed.

5. Ere fitting models using Chow tests or Lymr Hausman test model is suitable to estimate the model selected.

\subsection{Model is given as Follows}

The Null hypothesis and the assumption of the model are as follows: 


$$
\begin{aligned}
& \left\{\begin{array}{l}
H_{0}: \beta_{1}=\beta_{2}=\ldots=\beta_{4}=0 \\
H_{1}: \beta_{i} \neq 0 \quad i=1,2, \ldots, 4
\end{array}\right. \\
& H_{0} \text { : The model is suitable for } \\
& H_{1} \text { : Effects model is } \\
& \text { appropriate }
\end{aligned}
$$

The relation between control variable and in depended

\begin{tabular}{|c|c|c|c|c|}
\hline \multicolumn{5}{|c|}{ Dependent Variable: I/k } \\
\hline \multicolumn{5}{|c|}{ Method: Pooled Least Squares } \\
\hline \multicolumn{5}{|c|}{ Date: 04/08/13 Time: $21: 01$} \\
\hline \multicolumn{5}{|c|}{ Sample: 2005-2011 } \\
\hline \multicolumn{5}{|c|}{ Included observations: 6} \\
\hline \multicolumn{5}{|c|}{ Cross-sections included: 134} \\
\hline \multicolumn{5}{|c|}{ Total pool (unbalanced) observations: 802} \\
\hline \multicolumn{5}{|c|}{ White cross-section standard errors \& covariance (d.f. corrected) } \\
\hline Prob. & t-Statistic & Std. Error & $\begin{array}{l}\text { Coefficien } \\
\mathrm{t}\end{array}$ & Variable \\
\hline $0 / 353$ & $0 / 930$ & 0/098 & $0 / 091$ & $\mathrm{C}$ \\
\hline $0 / 000$ & $4 / 573$ & $0 / 018$ & $0 / 083$ & $\mathrm{CF} / \mathrm{k}$ \\
\hline $0 / 695$ & $-0 / 393$ & $0 / 020$ & $-0 / 008$ & $\log$ Size \\
\hline $0 / 001$ & $3 / 417$ & $0 / 107$ & $0 / 365$ & DEBT \\
\hline $0 / 525$ & $0 / 636$ & $0 / 034$ & $0 / 022$ & Growth \\
\hline $0 / 093$ & \multicolumn{2}{|c|}{ Mean dependent var } & $0 / 045$ & R-squared \\
\hline $0 / 329$ & \multicolumn{2}{|c|}{ S.D. dependent var } & $0 / 040$ & Adjusted R-squared \\
\hline \multirow[t]{2}{*}{$1 / 935$} & \multirow{2}{*}{\multicolumn{2}{|c|}{ Durbin-Watson stat }} & $9 / 406$ & F-statistic \\
\hline & & & $0 / 000$ & Prob(F-statistic) \\
\hline
\end{tabular}
variable as follows: $\left\{\begin{array}{l}H_{0}: \beta_{1}=0 \\ H_{1}: \beta_{1} \neq 0\end{array}\left\{\begin{array}{l}H_{0}: \beta_{0}=0 \\ H_{1}: \beta_{0} \neq 0\end{array}\right.\right.$

$$
\left\{\begin{array} { l } 
{ H _ { 0 } : \beta 2 = 0 } \\
{ H _ { 1 } : \beta 2 \neq 0 }
\end{array} \left\{\begin{array} { l } 
{ H _ { 0 } : \beta _ { 3 } = 0 } \\
{ H _ { 1 } : \beta _ { 3 } \neq 0 }
\end{array} \left\{\begin{array}{l}
H_{0}: \beta_{4}=0 \\
H_{1}: \beta_{4} \neq 0
\end{array}\right.\right.\right.
$$

\begin{tabular}{|c|c|c|c|c|}
\hline \multicolumn{5}{|c|}{ Dependent Variable: IWK/k } \\
\hline \multicolumn{5}{|c|}{ Method: Pooled Least Squares } \\
\hline \multicolumn{5}{|c|}{ Date: 04/08/13 Time: 21:02 } \\
\hline \multicolumn{5}{|c|}{ Sample: 2005-2011 } \\
\hline \multicolumn{5}{|c|}{ Included observations: 6} \\
\hline \multicolumn{5}{|c|}{ Cross-sections included: 134} \\
\hline \multicolumn{5}{|c|}{ Total pool (unbalanced) observations: 801} \\
\hline Prob. & t-Statistic & Std. Error & Coefficient & Variable \\
\hline $0 / 001$ & $3 / 339$ & $0 / 288$ & $0 / 962$ & $\mathrm{C}$ \\
\hline $0 / 393$ & $0 / 855$ & $0 / 036$ & $0 / 030$ & $\mathrm{CF} / \mathrm{k}$ \\
\hline
\end{tabular}

Table 1: Fixed Effects Model

Table 2: Model with Random Effects

\begin{tabular}{lllll}
\hline $0 / 056$ & $-1 / 911$ & $0 / 051$ & $-0 / 098$ & $\log$ Size \\
$0 / 176$ & $-1 / 356$ & $0 / 319$ & $-0 / 433$ & DEBT \\
$0 / 000$ & $3 / 575$ & $0 / 067$ & $0 / 239$ & Growth \\
Effects & Specification & & \\
Cross-section fixed (dummy variables) & \\
$0 / 416$ & Mean dependent var & $0 / 697$ & R-squared \\
$1 / 031$ & S.D. dependent var & $0 / 634$ & Adjusted R-squared \\
$1 / 738$ & Durbin-Watson stat & $11 / 122$ & F-statistic \\
& & $0 / 000$ & Prob(F-statistic) \\
\hline
\end{tabular}

Table 3: Model with Random Effects

Dependent Variable:I/k

Method: Pooled Least Squares

Date: 04/08/13 Time: 21:04

Sample: 2005-2011

Included observations: 6

Cross-sections included: 134

Total pool (unbalanced) observations: 802

\begin{tabular}{lllll} 
Prob. & t-Statistic & Std. Error & Coefficient & Variable \\
& & & & \\
$0 / 462$ & $0 / 737$ & $0 / 098$ & $0 / 072$ & $\mathrm{C}$ \\
$0 / 004$ & $2 / 915$ & $0 / 020$ & $0 / 058$ & $\mathrm{CF} / \mathrm{k}$ \\
$0 / 004$ & $2 / 889$ & $0 / 050$ & $0 / 145$ & $\mathrm{CF} / \mathrm{K}$ *Low \\
$0 / 806$ & $-0 / 246$ & $0 / 017$ & $-0 / 004$ & wk,Highwk \\
$0 / 000$ & $3 / 792$ & $0 / 096$ & $0 / 363$ & DEBT Size \\
$0 / 452$ & $0 / 752$ & $0 / 032$ & $0 / 024$ & Growth \\
$0 / 093$ & \multicolumn{1}{l}{ Mean dependent var } & $0 / 055$ & R-squared \\
$0 / 329$ & \multicolumn{2}{l}{ S.D. dependent var } & $0 / 049$ & Adjusted R-squared \\
$1 / 940$ & \multicolumn{2}{l}{ Durbin-Watson stat } & $9 / 263$ & F-statistic \\
& & $0 / 000$ & Prob(F-statistic)
\end{tabular}

Table 4: Model with Fixed Effects

Dependent Variable: IWK/k

Method: Pooled Least Squares

Date: 04/08/13 Time: 21:05

Sample: 2005-2011

Included observations: 6

Cross-sections included: 134

Total pool (unbalanced) observations: 801

\begin{tabular}{lllll} 
Prob. & t-Statistic & Std. Error & Coefficient & Variable \\
$0 / 001$ & $3 / 396$ & $0 / 290$ & $0 / 984$ & $\mathrm{C}$ \\
$0 / 276$ & $1 / 090$ & $0 / 040$ & $0 / 044$ & $\mathrm{CF} / \mathrm{k}$ \\
$0 / 470$ & $-0 / 723$ & $0 / 105$ & $-0 / 076$ & $\mathrm{CF} / \mathrm{K}^{*}$ Low wk,Highwk \\
$0 / 048$ & $-1 / 978$ & $0 / 051$ & $-0 / 102$ & $\log$ Size \\
\hline
\end{tabular}




\begin{tabular}{|c|c|c|c|c|}
\hline $0 / 173$ & $-1 / 366$ & $0 / 320$ & $-0 / 436$ & DEBT \\
\hline $0 / 000$ & $3 / 574$ & $0 / 067$ & $0 / 239$ & Growth \\
\hline \multicolumn{5}{|c|}{ Effects Specification } \\
\hline \multicolumn{5}{|c|}{ Cross-section fixed (dummy variables) } \\
\hline $0 / 416$ & Mean d & dent var & $0 / 697$ & R-squared \\
\hline $1 / 031$ & S.D. de & ent var & $0 / 634$ & Adjusted R-squared \\
\hline \multirow[t]{2}{*}{$1 / 737$} & Durbin & on stat & $11 / 037$ & F-statistic \\
\hline & & & $0 / 000$ & Prob(F-statistic) \\
\hline
\end{tabular}

\subsection{Baseline Specification and Estimation Methodology and Analysis}

In scientific research, statistical data analysis of collected samples, the study is considered, Is an important step because the researcher, at this stage, the final result will reach.

Using the same method will be concluded data is been analysis and hypothesis testing, and ultimately the final report done. In this chapter, information about companies in the period 2005-2011 were analyzed to test the hypothesis is to investigate the relationship between variables.

The data were calculated and analyzed using Excel software and (Eviews 6) and (Spss) were analyzed.

Data analysis included descriptive statistics, mean, standard deviation, mean, median, standard deviation, skewness and is persion indices of skewness and elongation as begun. These measurements have been performed separately and in total. Next, test he normality of the dependent variable evaluate using the test KolmogorovSmirnov test was performed. Analysis models for analyzing panel are used. The presence or absence of effects models (fixed or random) of the models and the best model is estimated.

Inferences are based on significance level or P-value or Significant Level, thus unlikely that any value or significance level of the test less than $05 / 0$ zero is rejected at $95 \%$ confidence.

\section{Discussion}

\begin{tabular}{l}
\hline (models no ) Confirmed-Reject \\
\hline 1) confirmed \\
2) confirmed \\
3) Confirmed \\
4) confirmed \\
\hline
\end{tabular}

\section{Conclusion}

We use a panel of over 134 stock firms over the period 2005-2011 to analyze the linkages between investment in fixed and working capital and financing constraints. We analyze relation between Investment, cash flow, tangible fixed assets, capital working and fixed investment and this suggests that an active management of working capital may help firms to alleviate the effects of financing constraints on fixed investment.

In a study inducted by CIA Ding and Gvargilio night, the effect of Working Capital Management on the fixed assets was accepted, which of course was tested and accepted via the stated assumptions and achieving the study goals.

\section{References}

[1] Sai, D., Alessandra, G., John, K., 2012. Investment and financing constraints in china, Journal of banking \$ Finance $18,1-18$.

[2] Allen, F., Qian,J., Qian, M., 2005. Law, finance, and economic growth in China, Journal of Financial Economics $77,57-116$.

[3] Ayyagari, M., Demirgüç-Kunt, A., Maksimovic, V., 2010, Formal versus informal Finance: evidence from China.Review of Financial Studies 23, 3048-3097.

[4] Chen, H., Chen, S., 2012, Investment - cash flow sensitivity cannot be a good Measure of financial constraints: evidence from time-series. Journal of Financial Economics 103, 393410 .

[5] Guariglia, A., Liu, X., Song, L., 2011, internal finance and growth: microeconometric Evidence on Chinese firms, Journal of Development Economics 96 (1), 79-94.

[6] Bernanke, B., Gurkanyan, R., 2001. Is Growth Exogenous? "Taking Mankiw, Romer, and Weil Seriously, National Bureau of Economic Research Annual, MIT Press, and Cambridge, Massachusetts".

[7] Bond, S., Schiantarelli, F., 2010, Capital accumulation and growth: a new look at Empirical evidence, Journal of Applied Econometrics 25, 1073-1099.

[8] Ding, S., Knight, J., 2011, why has China grown so fast? "The role of physical and human capital formation, Oxford Bulletin of Economics and Statistics 73, 141-174".

[9] Etemadi, H., Baghiyan, F; (2013), Investment and Financing Constraints in Iran, International Journal of Economics, Finance and Management Sciences (IJEFM) pp.252-257. 